\title{
Some principles of the formation and development of ethical terms in the English language in the XVI-XVIII centuries
}

\author{
Shukurova Madina Askarovna ${ }^{1}$, Djumayeva Nozima Djurabayevna ${ }^{2}$ \\ ${ }^{1,2}$ Teachers of the English linguistics department, Bukhara State University Republic of \\ Uzbekistan
}

Email:sh.madina 84@mail.ru

\begin{abstract}
Some principles of the formation and development of terms of ethics in the English language in the XVIXVIII centuries and different view points of specialists on this field are the main issues considered in this article. It also analyzes the linguistic nature of the social and ethical vocabulary of the English language of the XVI-XVIII centuries, as well as the specific features of the language of ethics and style inherent in the initial stage of the formation of a system of ethical and philosophical concepts in national English. The lexical-semantic way of forming the terminology of the ethical language of the research period is also considered in the article.
\end{abstract}

Keywords: principle, ethical terms, science, language, correlation, vocabulary, lexicography, lexical meaning, semantics, peculiarities, linguists, research, steps, phonetics, morphology, term, structure, development, penetration, process, diachronic, specification, factor, linguistics.

\section{INTRODUCTION}

In connection with the introduction of the system principle in the study of the history of language, the study of language as a dynamic system is of particular relevance $[1,76]$. The problem of the correlation of language and extra-linguistic reality at the present stage of the development of the science of language is one of the main ones, since "modern linguistics is again returning to understanding language as a global means of expressing the consciousness and psyche of a person" [2, 122].

Linguistics as an explanatory science is impossible without historicism, which finds its foundation in the nature of language, as a changing phenomenon [3,13]. Characterizing the internal stimuli and external factors of the evolution of the language, it is quite rightly asserted that "the enrichment of the vocabulary of the language refers to the phenomena of development." In the history of the English language, such is borrowing. Borrowing is a factor of evolution and an important source of development of a language, its vocabulary, since "vocabulary is the area of the language that is most "open" to all kinds of external influences, the area in which all changes occurring in the social and spiritual life of society". For English vocabulary, borrowing is a central theme, as evidenced by both the history of the English language and the history of lexicography.

In linguistic literature of recent years, more and more often appear statements about the importance and necessity of the revival of historical research in all aspects of the language $[4,66]$. A number of works emphasize the need to consider and analyze the linguistic phenomena of certain historical periods $[5,23]$.

\section{LITERATURE REVIEW}

When studying the vocabulary, the problem of its enrichment in the process of historical development of the language comes to the fore; The enrichment of the vocabulary goes on in certain areas, the nature of which is due to the conditions of the historical period $[6,16]$. In the works of Academician V.V. Vinogradov, the importance of studying the semantic development of both individual words and lexicalsemantic groups in historical terms has repeatedly been pointed out, which would make it possible to identify the characteristic features of the semantic development of the vocabulary of a particular language 
[7, 312], because "the study of the semantic history of words paints an objective picture of their meanings and the development of semantic content, which, firstly, simultaneously leads to the replenishment of the etymology of these lexical units and, secondly, determines the scope of their initial use during the period of borrowing from the source language to the recipient language. The solution to this problem is determined by the analysis of the semantic evolution of the word in new language conditions, the importance of which is beyond doubt" [8, 580]. Saidova M.U in her article "The problem of studying literary terms on lexical stylistic devices" (2019) gave historical analyses of literary terms and vocabulary of lexical devices as well.

\section{ANALYSIS}

There are a number of studies highlighting the various stages of the borrowing process, but there is no consensus on the very definition of foreign borrowing as a result of this linguistic process due to the lack of uniformity in understanding the latter. Let us briefly dwell on the main provisions of the above, since in our study borrowing makes up the vast majority of vocabulary of ethics of the XVI-XVII centuries. Even S.K.Bulich pointed out that "the phenomenon of linguistic borrowing is of interest for study in the sense that, perhaps, not so sharply the social basis and nature of the latter is manifested in any of the other phenomena of the life of the language. None of the other linguistic phenomena has such close and numerous connections with various factors of social life, and therefore also none of the linguistic phenomena is ... of such complexity and diversity, laughing at the researcher's attempt to put the facts related here to either a simple and clear system." By borrowing is meant the process of moving various elements from one language to another. By various elements we mean units of different tiers of the language - phonology, morphology, syntax, vocabulary, semantics. In general terms, this is the approach of different authors to understanding the term "borrowing".

Among the aspects of assimilation, one of the central and decisive places is occupied by the semantic assimilation of borrowing. Meanwhile, this side of the problem has not yet been theoretically illuminated and has not been developed practically properly yet. According to the researchers, this is explained by the fact that in most cases the semantic aspect of borrowing is considered in a range of other issues, and by no means the main ones, devoted to the problem of assimilation, which, naturally, does not make it possible to study this aspect in detail and sufficiently deeply. And it is not surprising that in recent years there has been an increasing interest in studying the semantic assimilation of borrowings.

In this work, we pay special attention to two main stages: "the moment of penetration" and "further development on new language ground", because the study examines the stages of borrowing in the receptor language for the first 100 years, and the first stage ("penetration moment") is equally important, the study of which makes it possible to consider the mechanism and specificity of this complex process.

The borrowed word in the work is considered in the lexical-semantic system of the English language, which is defined by us as "the entire field of semantic relations of lexical units, the peculiarity of their types of interaction with each other and with elements of other aspects of the language, the conditions and forms of linguistic expression of the results of semantic variation verbal signs [9, 251].

A borrowed word should be understood as "such a word, which, having penetrated the language, began to function in any sphere of human activity at a certain stage in the historical development of the language". Along with the word, the unit of linguistic description of the analyzed material at the lexicosemantic level adopted the lexico-semantic version (LSV). The semantic community of the vocabulary of ethics is established on the basis of the analysis of the context in which they are identified, as well as their vocabulary definitions. Various kinds of modifications in the graphic design of words are recognized as not relevant due to the fact that in the analyzed period the English language did not yet have a solid code of rules for the spelling of the literary standard [10,95].

A phrase means a semantic and grammatical combination of two full-valued words that are not a sentence $[11,10]$. Great help in determining the characteristics of the semantic assimilation of lexical units is given by analysis - in terms of synchrony or diachrony - of such objective parameters of the functioning of words as the genre representation of the analyzed vocabulary by establishing the authors who used a particular word, the nature of the works in which they are fixed, as well as an analysis of their combinatorial capabilities, i.e. taking into account their lexical co-accountability as a part of various models, analysis of the semantics of units combined with them. Such a method is especially useful when 
analyzing words with the same semantics (lexical correspondences), since it makes it possible to establish subtle semantic and stylistic differences, the facts of the predominance of a word or its LSW over competing words at a certain stage. A similar technique was proposed by K. B. Shadmanov [12, 76]. We also follow this path in our study of the semantic aspect of assimilation of the analyzed vocabulary.

\section{DISCUSSION}

The content of the words of ethical and philosophical vocabulary is fully disclosed only through their actual functioning, i.e. behavior in the text. Therefore, the material of this study was diverse in content and genre texts of representatives of the XVI-XVII centuries. (W. Shakespeare, F. Bacon, E. Spencer, F. Sidney, D. Donn and others), which are a rich source for studying the period of formation and design of the vocabulary of ethics.

When translating, we were guided by the definitions of The Shorter Oxford English Dictionary on Historical Principles (ed. Onions, Oxf., 1964), as well as special philosophical dictionaries of English and Russian authors were used as the main lexicographic source.

The influence of the Latin language on all levels of the English language is the most profound and wide in the XV-XVI centuries. Moreover, the syntactic structure of the English language of that period was, according to many researchers, one of the most permeable levels, due to three reasons: 1 . the influence of the substrate; 2. cultural impact in the collision of two languages; 3 . the influence of translations from one language to another and penetration from the original language of those syntactic turns into which this document is translated. The formation and development of new language models is carried out as a result of the conscious efforts of the speakers and proceed under their more or less clearly conscious control.

It is well known that mutual influence as an important factor in the historical development of many languages can play a significant role in the formation of different styles within a literary language as a result of the direct influence of bilingualism or a language that is actual in a certain historical period (for example, Latin). An example is the process of forming the style of the language of philosophy in the system of English literary language in the XVI-XVII centuries under the direct influence of classical languages. It is very important to understand the special role of Latin during this period and to reveal its linguistic status in the fate of the English national language that is the fact that the English language penetrates not so much isolated, albeit significant in its units, but the fact that large, integral semantic and structural groups. This also shows the peculiarity of the formation and formation of English philosophical vocabulary within organized thematic groups.

Let us dwell on the types of syntactic models and their foreign language basis in order to explicate convenient identification milestones of a written variety of a literary language and limit it from oral-spoken variants. When considering semantic and syntactic parameters, we found that the functioning of borrowings of the XVI-XVII centuries. characterized by the following features. 1. An analysis of the syntagmatic connections of the studied vocabulary reveals the main models of combinations and their partners in the context in the initial period: a) nominal - N + prep $+\mathrm{N}(\mathrm{N}+$ of $+\mathrm{N})$; Pron $+\mathrm{N}$ (Pron pers $++\mathrm{N} ;$ Pron ind $+\mathrm{N}) ; \mathrm{N}+$ conj. $+\mathrm{N} ; \mathrm{N}+$ and $+\mathrm{N} ; \mathrm{N}+$ or $+\mathrm{N} ; \mathrm{A}+\mathrm{N} ; \mathrm{b}$ ) the verbal $-\mathrm{V}+$ prep $+\mathrm{N} ; \mathrm{V}$ mod. $+\mathrm{N} ; \mathrm{V}$ be $+\mathrm{n}$.

Despite a certain limitation of the semantic structure, the analyzed vocabulary enters into all kinds of combinations with both full and official words. Limitations in the use of constructions of various types in the initial period of functioning of these new arrivals in the English language were not found. 2. During the first hundred years on the basis of the borrowing language, the number of constructions increased. They are characterized by a variety of structures. In particular, models were added that were not fixed in the initial period of borrowing in the recipient language: Ns + and + Ns; Ns + prep + Ns; N's $+\mathrm{N} ; \mathrm{N}+$ to $+\mathrm{N} ; \mathrm{Num}+\mathrm{N} ; \mathrm{N}+$ upon $+\mathrm{N} ; \mathrm{N}+$ of + Pron. With the dominance of two-component combinations, among which the most common model is $\mathrm{A}+\mathrm{N}(\mathrm{Adj} .+\mathrm{N})$.

A significant expansion of the number of combinations in the $\mathrm{N}+$ prep $+\mathrm{N}$ model is also noted, where the range of prepositions used is increasing. Clarification of the preposition in the model $\mathrm{N}+$ prep $+\mathrm{N}$ leads to the formation of its variety of type $\mathrm{N}+$ between $+\mathrm{N} ; \mathrm{N}+$ upon $+\mathrm{N} ; \mathrm{N}+$ with $\mathrm{N}$, the frequency of occurrence of models characteristic of the initial period also increases. 
Analysis of phrases with borrowings of the XVI-XVII centuries revealed the presence of 9 basic models, while in the modern English language 23 models are generally accepted. This suggests that during the study of the complete design of all currently known models, it has not yet been observed: the lack of strict norms of literary use affects it. The most common were the prepositions of and in, the positions of which were further strengthened in the future, i.e. the frequency of their occurrence increased, and prepositions between, with, upon were added, inferior in this parameter only to the preposition of, which conveys the most abstract attributive relations (cause of ratiocination, inequality of, of coherence, gradation of consequence).

The preposition on is rarely used in the 16th-17th centuries, and is not registered at all in the 16th century. The prepositions of, in, with, which are characterized by a high frequency in modern English, were such in the XVI-XVII centuries, the prepositions between, upon, currently classified as lowfrequency, in the XVI-XVII centuries had a high frequency of occurrence.

At first, borrowed innovations were combined with a limited circle of lexical units (both primordial and borrowed) - from 1 to 5 words. Most of the analyzed words are combined with two lexical units in the first decades of their existence on English soil. In the future, the lexical valency of the analyzed words increases significantly - from 2 to 32 .

The following words are most active: fact, agent, modesty, coherence, medium, levity, anticipation, etc. In this regard, with rare exceptions (except for the words elucidation), most of the analyzed 1. e. very active. The circle of words combined with the borrowings of the 16th-17th centuries consists of vocabulary commonly used and different in etymology.

The components of phrases with the analyzed lexical units of the XVI-XVII centuries belong to different parts of speech; nouns predominate; followed by the adjectives and in the third position - verbs.

From the point of view of semantics, the combined vocabulary (in parts of speech) falls into: Verbs: a) specific action: show, hide; b) movements: move, follow, quit; c) perceptions: see. feel; e) mental perception: know, conceive; e) words of general semantics: do, become.

Nouns: a) proper: Jeroms', Lucretias', Adams', Wallenstein, Thonas Ave; b) collective: Greeks', Romans, men. women c) names of professions, positions, positions: master, mere-hand, cardinal, Emperor, Prince; d) religious character: God, Angel, soul; e) abstract: observation, harmony, cooperation, sequence, uniformity, process, cause, judgement, consequence, evidence.

Adjectives fall into several groups expressing: a) an emotional assessment: pretty, dearest, sweet, marvellous, great; b) quantity: all, many, full of; c) certain features: bashful, English, mild, sober, vesta; d) qualitative characteristic: 1) suddenness - sudden, accidental, causal, unusual; 2) with a negative rating - ungodly, shame fast, indecent, cruel, ill; 3) with the positive - generous, wrathful. Pronouns: any, some, my, those, this, all. Prepositions: in, with, by, for, of, from, to.

The saturation of emotional-evaluative vocabulary, typical of many works of the XVI-XVII centuries, is also characteristic of the analyzed vocabulary, which finds its syntactic expression in the A + $\mathrm{N}$ model.

We confirm that the depersonized style of presentation that was prevailing in the modern English scientific text was not the norm for the English scientific text during its formation: the texts studied by us are typical of the first-person manner, and it is noted that in the English text of the XIV-XVII centuries philosophical words the personal pronoun "I" can conditionally distinguish two semantic nuances: 1) associated with a specific physical action; and 2) related to assessment, judgment, intentions. This revealed a very interesting picture: a) the author's "I" in texts, where the lexical unit of a philosophical character borrowed in the XVI-XVII centuries was first used at the time of borrowing, in combination with the verbs of "physical action" was not recorded at all, but in combination with the verbs of "judgment" (including those of the same centuries) only once. During the first 100 years, there has been a sharp increase in the use of the author's "I", and the combinations of the personal pronoun "I" with the verbs of "assessment" are twice as many as with the verbs of "action", which confirms the objective trends in the development of philosophical thought in the 17th century, when philosophy began to focus on experimental science (F. Bacon), and the thinker had to not only collect, but also process, not only contemplate, but also generalize in his knowledge of the surrounding activity. Moreover, it is noted that the verbs think, see, perceive, (could, would), wish give an evaluative character to a statement related to experiment, observation, judgment, methodology); b) the use of personal pronouns indicates the 
manifestation of the influence function in a scientific style, which is an integral part of a philosophically directed text. The form of the personal plural pronoun (we), which is more consistent with the nature of scientific activity today, is of undoubted interest in terms of acquiring new semantic meanings, which are caused by the pragmatics of the scientific text.

It is known that during the early English period a system of formal members of phrases is created that either do not have their own lexical meaning or are filled with the lexical meaning of the word whose syntactic position they replace (one, that). There arises the obligatory completeness of the substantive phrase - the official noun one. A little earlier - in the Middle English period that (those) appeared. There arises the obligatory completeness of the substantive collocation, which consists in the fact that the leading member of the collocation cannot be absent: it is always presented either lexically or grammatically. There is a process of the influence of ethical words as belonging to a certain layer on the general literary vocabulary, namely: the analyzed borrowings of the 16th-17th centuries involve the combined vocabulary in their orbit, giving it specialized meanings and, ultimately, terminizing it in a certain way: a) nominal - process of ratiocination, discourse of ratiocination, elucidation of doctrine, materiality of world, gradation of consequences, accidental identity, experience of modesty; b) verbal - to commit fact, to impeach modesty, to be inconsequence, to dissolve penalty.

The use of ethical and philosophical vocabulary in the variety of genres is one of the characteristic features of literature of the XIV-XVII centuries. Moreover, the diversity of the genre is characteristic of both a single author, whose creative baggage is characterized by the variety of works created by him, as well as the various works of thinkers who are inherent in the uniformity of the genre (T. Eliot, etc.).

At the same time, the acquisition by words of new meanings, shades for expressing ethical thought indicates that there is a process of gradual professional differentiation of the ethics language in connection with the specialization of knowledge, its registration as a separate science (anticipation; consistence; gradation, fact). Differences in the meanings of the same borrowing, which are not accompanied by a violation of his identity, the appearance of two or more ethical and philosophical meanings in it is the result of the expansion of the semantic boundaries of the unit due to the development of internal semantic capabilities. The connection of the etymological meaning with the borrowed in English is figurative based on associative signs associated with the word in its main sense in the etymon language (coherence, semination).

The peculiarity of term-creation in the field of ethics of the period is determined by: a) special semantics; b) special use directly related to the field of ethics; c) its interdisciplinary nature; d) a wide range of vocabulary and, as a result, stratification of terminology into narrow terminological systems; e) direct regulation of words in the field of fixation and functioning, which is determined by the need for an adequate transmission of the meaning of the concept used, which has as its goal a unified interpretation. In addition: the movement, crystallization of the semantic structure of a unit of ethical order in the direction of their terminization in the early period of the formation of the English language of ethics is, mainly, the result of splitting the broad, in the past, meaning in the direction of its narrowing; the extralinguistic basis of moral didactic texts influences their lexical composition both from the point of view of stratification and in terms of filling each of its layers; in the ethical and philosophical narrative, some lexical units of a commonly used layer of vocabulary are able to shift towards a layer of ethical terminology and form a special subsystem of ethical vocabulary; in the choice of vocabulary of a text of an ethical-moral order, the subjective-emotional assessment of events by the thinker is reflected; the secondary nature, borrowing - for the most part - of the English ethical terminological system is largely due to the high susceptibility of the English language of the study period to borrowing in general and to term creation, in particular; the potentially realized volume of special designations, especially at the early stage of the formation of the English ethical terminological system, most often has its source in the common words of the English vocabulary of the late Renaissance - the latter became a term, already possessing a clearly defined semantic and stylistic orientation in a non-special literary language.

In order to establish general tendencies that multidimensionally characterize the basic composition of the thematic vocabulary of ethics, it becomes necessary to trace the transformations determined by the time factor. First of all, this refers to the semantic field, and, as M.A. Halliday aptly observes, the line between changes of an intralingual nature and socially determined ones is very vague 
$[13,157]$. This remark is very useful in connection with the analysis of vocabulary of an ethical nature, which, as you know, plays a special role in shaping the thinking of the nation.

The evolution of a term system is determined, as is well known, by the needs of social development. So, G. Savory believes that scientific vocabulary does not change meanings during the course of tables, explaining this by its stability in form and function, which allows the transfer of knowledge from generation to generation $[14,51]$. The point of view of other researchers is somewhat different, who believe that the terms of science are more isomorphic than the words of an ordinary language, since they have a greater semantic content (Nalimov V.O., Turkin, Andrews, etc.). The validity of the above points of view cannot be disputed, provided that we are talking about a structurally stable and in many ways really isomorphic, nomenclature, say, chemical, medical, etc., although this nomenclature, as is commonly believed, is not element of the terminological system. However, when it comes to the period of formation, formation and enrichment of the vocabulary of the English language of ethics, this point of view can hardly be considered true without reservations.

Indeed, terminological vocabulary develops in many cases faster than general vocabulary, because the need for a terminological system that forms itself into an independent branch should be provided with optimal language means when scientific thinking is ahead of the everyday. This, in turn, is due to the more flexible semantics of terminological systems and the dynamism of the terms themselves, allowing them to reflect not only certain scientific concepts, but also capture potential changes in a particular scientific field, as well as directly in the scientific worldview.

It should be noted that the interaction of the semantics of lexical units is a complex phenomenon, and in some cases we are talking about the intersection of words in similar meanings, while in general there are large differences in their semantic structure. Moreover, arising in the XVI-XVII centuries the new vocabulary of the analyzed vocabulary also encounters the meanings of words already existing in the English language. The identification of the specifics of such a partial correspondence, leading either to the displacement of one by the other, or to their subsequent differentiation among themselves, is also possible only as a result of an objective consideration of the main parameters of their functioning in the lexicalsemantic system of the borrowing language.

L.S. Barkhudarov indicated cases of partial correspondences, in particular, intersection relations, when only a partial coincidence of meanings is observed between two words, but already one in which the circle of meanings of words, say, in language A cannot be fully included into the circle of meanings of a word in the language $[15,12]$. Since these words have both coincident and diverging meanings. He also cited the causes of these phenomena. These provisions are accepted by us as the starting point in the analysis. If the meanings coincide, we can talk about the complete assimilation of the term in a semantic sense, if the analyzed word of an ethical nature clearly prevails over the interacting word in the above parameters: then essentially the process of crowding out one word with another, usually ending with the complete loss of the last from dictionary composition.

The study of the semantic aspect of the assimilation of words of an ethical nature is carried out both on the line of considering the process of establishing their semantic structure in English soil, and on the line of studying those transformations that are caused by the interaction of new borrowings of an ethical-philosophical order with the prevailing vocabulary of the perceived of the language Particular attention is paid to two main stages: the "moment of penetration" and "further development on new linguistic soil", because in our study we consider the stages of development borrowings in the receptor language for the first hundred years, and the first stage seems to be important, the study of which makes it possible to consider the mechanism and specificity of this complex process in the light of the new world understanding and thinking of the representatives of the era and their nationally justified desire for ordering and systematization of vocabulary and vocabulary of the English national literary language.

The use of ethical vocabulary in the vast majority of genres is one of the characteristic features of the literature of the era. At the same time, the acquisition by lexical units of new meanings, shades, characteristic of the expression of moral and ethical thought, indicates that there is a process of gradual professional differentiation of the ethics language in connection with the specialization of knowledge, its registration in a separate science (anticipation, concurrence, gradation etc.): "anticipation is when we prevent those wordes that another would saie" (T. Wilson. Rtet. 100); "So shall my anticipation prevent your discovery" (Shaks. Haml. 11.2. 304). 
Unambiguous lexical units have a low frequency, but they have a high degree of semantic autonomy, independent of context (modesty, presupposition, ratiocination), "..is according to unto the light and presupposition of that which is delivered" (F.Bacon. Adv . L. 11.126); "withot any discourse of reason, or ratiocination" (Holland Plutarch, Mog. 1344); “..Be pastime passing excellent, if it be ... with modesty" (Shaks. Ind. 1.66); "The that which maiden modestie doth warrant, bet all my sins look meray" (Ado. IV. 181).

There is a distinct difference in the meanings of the same word, which are not accompanied by a violation of its identity; the appearance of two or more different ethical and philosophical meanings in a word is the result of the expansion of the semantic boundaries of the word due to the development of its internal semantic capabilities (modesty, compendium, quiddity, vacuity, expectation, levity).

By its origin, ethical vocabulary is divided into: 1) words arising from the nation-wide native vocabulary and 2) words borrowed from other languages. Some features of introducing new borrowed units into circulation were noted: a) author's interpretations in dictionaries, where simplicity and clarity of presentation are characteristic by nature; b) periphrases - usually through descriptive translation or through the use of synonyms, for example: ratiocination is, that cometh of logie of any Commodity, or to ecaheve any discomodity, levity, lightnesse, inconstancie;

In some cases, not only the terminological LSW of the analyzed, but the whole set of lexical unit values differs in terminology, a narrow scope: ratiocination, anticipation, presupposition.

It is necessary to distinguish words that relate to the vocabulary of ethics and express important, fundamental concepts of this sphere (fact, coherence, modesty, levity), from words that are philosophical terms in the analyzed period: ratiocination, gradation, medium, ubiquity, presupposition).

The manner of presentation in the first person was typical in the analyzed era (letters, sermons, pamphlets, poetry), which is confirmed by the predominance of personal active forms of the verb, in which there is a semantic connotation of appreciation, the author's "I", as well as a personalized form expositions (psalm, poetry, treatise), reflected in the selection of vocabulary, especially with the verbs of physical action and with the verbs of "assessment, judgment, intention". In this regard, it turned out that in the initial period, on the basis of the recipient language, the author's "I" does not occur with the use of the analyzed words in conjunction with the verbs of physical action, and only with the verbs of "assessment, judgment" only once, while during the first 100 years there has been a significant use of the author's "I", and the verbs "assessment, judgment" are almost twice as active as the verbs of physical action (digital indicators 22 and 14, respectively). The scope of the analyzed lexical units is not limited to special literature; These words, as an active part of the vocabulary of the language, are of great importance in the everyday communication of people associated with the problem of moral and philosophical understanding of reality and, as a result, an attempt to independently comprehend certain concepts of "forces outside of man."

Lexical units of an ethical nature in the XVI-XVII centuries. used in various genres (modesty, levity, constancy, coherence), expressing the moral and ethical qualities of man. The attraction of these groups is due to the fact that they are characterized by abstractness, are used mainly in the style of written speech (F. Bacon, Shakespeare, T. Grafton, J. Milton, Stow, G. Fletcher, Cox).

For example, the compatibility of the lexical unit ratiocination in the first 100 years on English soil: process of-; discourse of-; reason or-. 15 Latin innovation words have conjugation with words with similar (but not matching semantics): anticipation, coherence, correlation, elucidation, education, gradation, identity, levity, modesty, materiallity, penalty, ratiocination, reflex, transition. These words, as we believe, being an integral part of the common vocabulary, serve as an intermediary in replenishing the reservoir of ethical and philosophical vocabulary.

A certain number of conjugating words arising within the framework of one (XVI) century are distinguished: hardheartedness, falsity, deceitfulness; perspicuity; inclination; reflection; the vulgar; forecast; epitome. The polysemy of semantics of these conjugating words that expressed a particular concept, observed in English of a more ancient period and in the Middle Ages, gives way to a clearer and more unambiguous expression of a concept in the 16th-17th centuries. 


\section{CONCLUSION}

The results of comparing the semantic structure of the units under study in the analyzed period and in modern English (based on the material of literary-book style nouns) confirms the working hypothesis about the comparative simplicity of the structure of the semantic structure of ethical and philosophical words $[16,16]$.

English vocabulary of ethics acts as a complex multidimensional system, characterized by the presence of numerous transitional cases, reflecting, thus, the complexity of the relationships and interconnections of its constituent units. This vocabulary is also subject to processes that are characteristic of all borrowings of the 16th century.

Thus, the vocabulary of ethics appears before us as a single, integral system, subordinated to certain objective laws of history and thinking, reflecting the really existing dialectic relationship and the further development of the most important ethical concepts, the worldview of representatives of the 16th17th centuries. It is significant that in the foreground is that part of the vocabulary that is directly related to the central concepts of the philosophy of humanism and enlightenment (reflex, modesty, levity, identity, coherence, anticipation, education, correlation).

The era of the XVI-XVII centuries most decisively influenced not only the content, but also the composition of the ethics dictionary, as evidenced by the appearance in the era under study of a large number of words to explain the new worldview and world outlook in the light of the revolutionary scientific discoveries of the era. The presence of words of an ethical and moral order among playwrights, poets, theologians suggests that their authors have mastered a new understanding of the world, and were also well acquainted with the basic works of the ethical and philosophical nature of the Old and New Times, with the vocabulary used in such works.

\section{REFERENCES}

1. Budagov R.A. Chto takoye razvitiye I sovershenstvovaniye yazika? - M.: Nauka, 1977-S.76.

2. Yarseva V.N. Razvitiye nasionalnogo literaturnogo angliyskogo yazika. - M., 1964 -S.122.

3. Ufimseva A.A. Slovo v leksiko-semanticheskoy sisteme yazika. - M. Nauka,1974 - S.13.

4. Shadmanov K.B. Osobennosti angliyskoy filosofskoy misli I leksiki XIV-XVII vekov. - T.: TFI, 2003 - S. 66.

5. Donskoy V.F. Glagolniye frazeologicheskiye yedinisi,oboznachayushiye nachalo I kones jizni cheloveka v yazike novoangliyskogo perioda: Avtoref.dis...kand.filol.nauk. - M., 1977 - S. 23.

6. Krasilnikova M.S. Proisxojdeniye, semanticheskaya struktura i nekotoriye sintagmaticheskiye svyazi angliyskix imyon sushestvitelnikh literaturno-knijnogo xaraktera: Avtoref.dis...kand.filol.nauk. - M., 1978. - S. 16.

7. Vinogradov V.V. Leksikologiya I leksikografiya. Izbr.trudi. - M.: Nauka, 1977 - S. 312.

8. Ufimseva A.A. Slovo v leksiko-semanticheskoy sisteme yazika. - M. Nauka, 1968 -1980-S. 580 .

9. Ufimseva A.A. Slovo v leksiko-semanticheskoy sisteme yazika. - M. Nauka, 1968 -S. 251.

10. Yarseva V.N. Razvitiye nasionalnogo literaturnogo angliyskogo yazika.-M.: Наука.1969 - S. 95.

11. Barxudarov G.S. $\mathrm{O}$ znachenii $\mathrm{i}$ zadachakh nauchnikh issledovaniy $\mathrm{v}$ oblasti terminologii//Lingvisticheskiye problem nauchno-texnicheskoy terminologii. - M.: Nauka, 1980. - S. 10 .

12. Shadmanov K. Osobennosti stanovleniya i razvitiya angliyskoy filosofii Vozrojdeniniya (kategorialno-ponyatiyniy aspekt): Dis. doktora filos.nauk.-T., 2006.

13. Halliday M.A. Langunage as Social Semiotic.- L., 1989. -P.157.

14. Saidova M.U. The problem of studying literary terms on lexical stylistic devices. // International Journal of Recent Technology and Engineering (IJRTE) ISSN: 2277-3878, Volume-8, Issue3S,July 2019

15. Savory T.H. The Language of Science: its growth, character and usage. -L., 1967. -P.51 
16. Barxudarov G.S. O znachenii i zadachakh nauchnikh issledovaniy v oblasti terminologii//Lingvisticheskiye problem nauchno-texnicheskoy terminologii. - M.: Nauka, 1980. - S.12.

17. Krasilnikova M.S. Proisxojdeniye, semanticheskaya struktura I nekotoriye sintagmaticheskiye svyazi angliyskix imyon sushestvitelnikh literaturno-knijnogo xaraktera: Avtoref.dis...kand.filol.nauk. - M., 1978. -S.16. 